\title{
Everyday and Cosmo-multiculturalisms: Doing diversity in gentrifying school communities
}

\section{Christina Ho, Eve Vincent and Rose Butler}

\section{Summary:}

Gentrification is transforming the class and ethnic profile of urban communities across the world, and changing how people deal with social and cultural difference. This paper looks at some of the social consequences of gentrification in Sydney, Australia, focusing on local schools. It argues that in this urban Australian context, the influx of middle-class AngloAustralians into traditionally working-class, migrant-dominated areas is significantly changing how people relate to each other within local schools, often fragmenting and dividing school communities. These shifts are intensified by the public policy of school choice, which has enabled some parents to bypass their local school for a more 'desirable' one. This paper presents a close local study of two schools within one gentrifying Sydney suburb, examining how the schools have become more polarised. In particular, we examine how this demographic polarisation has given rise to two distinct modes of 'doing diversity', namely, everyday and cosmo-multiculturalisms. While the former is about daily, normalised encounters across difference, the latter is a form of multiculturalism based on strategic and learned 'appreciation' and consumption of difference, characteristic of gentrified communities.

Author bios:

Dr Christina Ho is a Senior Lecturer in the Faculty of Arts and Social Sciences at the University of Technology Sydney. She researches cultural diversity in Australia, with a focus 
on inter-cultural relations within urban settings. Her current research is on school communities and education cultures in diverse areas, and inter-cultural relations between residents within high density housing. Her most recent book, co-edited with Andrew Jakubowicz, is For those who've come across the seas: Australian multicultural theory, policy and practice (Australian Scholarly Publishing 2013). Correspondence to: Christina Ho, Faculty of Arts and Social Sciences, University of Technology Sydney, PO Box 123, Broadway, NSW 2007, Australia. Email: christina.ho@uts.edu.au

Dr Eve Vincent is a lecturer in the Department of Anthropology at Macquarie University. She is the co-editor of History, Power, Text: Cultural Studies and Indigenous Studies (UTS EPress, 2014). Eve undertakes ethnographic research in Aboriginal Australia.

Dr Rose Butler is a Research Associate in the Centre for Social Impact at UNSW Australia. Her research areas include children and youth; young people, family and the economy; education and social change; and social inequality. 


\section{Everyday and Cosmo-multiculturalisms: Doing diversity in gentrifying school communities}

Many urban areas in western nations are experiencing dramatic change caused by gentrification, as middle-class professionals move into historically working-class suburbs. Gentrification is also often racialized, with gentrifiers typically comprised of white households, who come to coexist with older generations of non-white residents. This paper examines how evolving racialized and classed social relations create new ways of 'doing diversity’ within local communities. In particular, it identifies two modes of multiculturalism - ‘everyday multiculturalism’ (Ang et al 2002, Wise and Velayutham 2009) and ‘cosmomulticulturalism' (Hage 1998) - which provide contrasting models for understanding how people relate to ethnic 'others' and consolidate and express their own affiliations and values.

We focus on public primary schools as microcosms of local communities, examining the experiences of two schools within one gentrifying suburb in Sydney, Australia. The international literature on gentrification has highlighted the importance of schools in shaping urban change. Butler and Robson (2003: 24) note that in the UK, '[e]ducation markets are now rivalling those in housing and employment as determinants of the nature, extent and stability of middle-class gentrification.' Similarly, Hankins (2007: 113) argues that urban researchers should examine city schools as ‘new geographies of gentrification’. Focusing on schools also enables research on an under-examined group of gentrifiers: parents. As Billingham and Kimelberg argue, gentrification research has concentrated disproportionately on young singles and childless couples, creating a 'myopic perspective on the life cycles of middle-class urbanites’ (2013: 86, see also Hankins 2007). 
On a practical level, public schools are a key site for understanding broader community-level changes, especially primary schools, which are more likely (than secondary schools) to reflect their local neighbourhoods. At the same time though, policies encouraging 'school choice' enable parents to send their children to non-local schools, giving rise to new divisions and inequalities, which often mirror processes of gentrification itself. While school choice has always existed for parents considering private schools, it is now also increasingly common to choose between public schools. As a result, as we will show, there is increasing polarisation within the public system, as well as, of course, between the public and private systems.

Our small-scale study has found that the combination of gentrification and school choice policies has led to a polarisation between the schools in our target suburb, where some school communities have become wealthier and whiter, while other schools have a more disadvantaged profile. This aligns with international literature on the class and ethnic divisions caused by school choice policies. However, this paper also delves deeper, examining how this segregation shapes everyday interactions and perceptions within school communities. It distinguishes between two approaches to dealing with diversity: everyday and cosmo-multiculturalism.

\section{Gentrification, schooling and diversity: Everyday and cosmo-multiculturalisms}

Gentrification describes the process whereby wealthier people move into historically poor neighbourhoods, typically in the inner city, gradually transforming the status of the area. The term was coined by British geographer Ruth Glass (1964), describing the emergence of a new 
urban 'gentry', or aristocracy, in 1960s London, when it became fashionable to own a city residence for part-time use, in addition to the country home.

Gentrification is often associated with urban renewal, restoring degraded housing, obsolete buildings, and under-utilised land, to create newly vibrant residential areas (Tonkiss 2005: 87). In Sydney, from the late 1980s, new service jobs in retail, finance and information had emerged in the CBD and inner city. This has led to the influx of middle-class professionals, who have found inner-city living more attractive than the suburbs (Bounds and Morris 2006; see Bridge and Dowling 2001 for a detailed history of the gentrification of inner-Sydney suburbs).

Gentrification therefore, at least initially, enhances the social and cultural diversity of an area. Cultural diversity is often a drawcard for gentrifiers, attracted to the cosmopolitan aesthetic of an area symbolically associated with migrants. Often members of the 'new middle class', gentrifiers are ‘diversity-seekers’ (Blokland and van Eijk 2010), more inclined to find a diverse neighbourhood attractive, compared to higher income earners. Some may be part of Richard Florida's ‘creative class', who pride themselves on their tolerance and enjoyment of diversity (Florida 2003). Cultural diversity is associated with the values of an 'urban lifestyle', as opposed to the stereotypical culture of the suburbs (Ley 1986).

These social environments are potential sites of 'everyday multiculturalism', in which ordinary interactions occur across cultural difference within people's daily lives. Scholars of everyday multiculturalism (e.g. Ang et al 2002, Wise and Velayutham 2009, Harris 2013, Harris 2014, Butcher and Harris 2010, Ho 2011) have focused on sites such as neighbourhoods, workplaces and schools, arguing that interactions in these spaces represent a 
lived cosmopolitanism, in which people from different cultures routinely negotiate their coexistence within a shared social space. Routinised encounters with cultural difference normalise this difference, enabling an openness to ethnic others. Noble (2013) describes this as a 'banal cosmopolitanism’ or a ‘intercultural conviviality’, in which individuals pragmatically engage with people and goods from other cultures in daily practice, making multiculturalism an ordinary feature of life.

Schools have been theorised as a social space that may be particularly conducive to this kind of cross-cultural interaction. Amin describes schools, along with workplaces and other social sites, as 'micropublics of everyday social contact and encounter' (2002: 959), where people are thrown together and required to engage with each other and work together in a common activity, in the process enabling ‘unnoticeable cultural questioning or transgression' (2002: 969, see also Ho 2011).

A more cynical view of gentrifiers' appreciation of diversity has also been articulated within the literature, namely, that it is primarily a means for displaying cultural capital. Workingclass and ethnic others exist simply as objects of an ‘exotic gaze’ (May 1996: 208), a ‘colourful backdrop against which to play out a new urban lifestyle’ (May 1996: 196), or in Bridge’s terms, part of a 'gentrification aesthetic' (Bridge 2006).

Hage (1998) calls this 'cosmo-multiculturalism', in which members of the white majority engage with cultural difference through consumption. Hage explains (1998: 201) that the cosmopolitan person is 'capable of appreciating and consuming "high quality” commodities and cultures, including “ethnic” culture'. He argues that accumulating cosmopolitan capital requires a ‘competence to enjoy ethnic cultural diversity’, for example, appreciating ethnic 
cuisine (Hage 1998: 204; see also Bridge and Dowling 2001). It is a detached form of 'multiculturalism without migrants' (Hage 1997: 99), where cultural otherness becomes a commodity: ‘abstract ethnic value’ (Hage 1997: 145).

Hage's notion of 'cosmopolitan capital' draws on Bourdieu’s notion of 'cultural capital', which underpinned the latter's analysis of the reproduction of class privilege and the embodied dispositions learnt and displayed through the 'habitus' (Bourdieu 1984, 1986). Bourdieu defined the 'habitus' as a set of practices inculcated throughout childhood, and which become a set of 'bodily dispositions' that serve as an asset, liability, or both, in the future (Bourdieu 1984: 166). Differences in habitus give individuals varying cultural skills, social connections, educational practices and other cultural resources. These can be translated into different forms of value, or capital (Lareau 2003: 273). In Bourdieu’s analysis, the internalised nature of cultural capital and its transformation into particular forms of symbolic capital among the habitus of elites makes it 'the best hidden form of hereditary transmission of capital' (1986). It is this 'competence' to which Hage refers in his criticism of the cosmopolitan elite, where particular ways of appreciating 'others' become a sign of competitive cosmopolitan competency, serving to differentiate this elite from others, who are deemed 'racist', unsophisticated and backward (Hage 1997:131).

The literature on gentrification and schooling provides evidence for both approaches to multiculturalism. Research has shown that middle-class gentrifiers' embrace of diversity often stops at the school gate. In other words, gentrifiers' 'desire to display symbolic capital may conflict with the need to reproduce cultural capital through the education system’ (Boterman 2013: 1130). Despite their desire for an urban lifestyle, many gentrifiers are not willing to risk their children's education by sending them to an inner city public school 
dominated by working-class ethnic minority students (Butler 2003, Bridge 2006, Boterman 2013, Hamnett et al 2013, Roda and Wells 2013). Instead, they may relocate to the suburbs or choose a private school, in order to 'safeguard’ their children's education.

However, other research demonstrates that some middle-class parents are willing to engage with inner-city schools, for ideological reasons (commitment to public education or to local community institutions) or pragmatic reasons (not wanting to move, willingness to 'see how it goes'). Others opt for a collective middle-class strategy to enrol their children in local schools to create 'safety in numbers’ (Boterman 2013: 1134). In some schools, gifted and talented programs attract middle-class parents to otherwise 'undesirable' schools (Roda and Wells 2013, Raveaud and Van Zanten 2007). Others set up independent charter schools (Hankins 2007). All of these middle-class parents typically devote large amounts of time and money, as well as leveraging their professional networks, to ensure the quality of their children’s schooling experiences (Billingham and Kimelberg 2013, Cucchiara 2013a, PoseyMaddox 2013).

For Reay et al (2007: 1045), a 'self-interested altruism' explains some middle-class parents' support for local public schools. These schools are seen as best able to develop their children’s 'multiculturalist capacity' (being able to deal with ‘all types of people’), which will be valuable for their professional lives in a globalising economy. The accumulation of this cultural capital is a strategy for securing their class position (Reay et al 2007: 1046). The appeal of giving children a 'real world' experience in their schooling is well documented (Cucchiara 2013b, Kimelberg and Billingham 2013, Roda and Wells 2013). 
This paper examines the prevalence of each type of multiculturalism within our two target schools in Sydney. It highlights relationships between gentrification, school choice, and different modes of dealing with diversity. First however, we explain the context of choice and inequality within the Australian education system.

\section{School choice and polarisation: The Australian context}

In Australia, gentrification has unfolded alongside the creation of a 'market' in schools, as successive governments have favoured a 'school choice' model. Conservative governments, especially, have argued that school choice is an extension of democratic rights, and that competition between schools creates better schools for everyone (Kelly 2009: 263). Since the early 1970s, federal governments have steadily increased funding of non-government schools (Forsey 2010a: 2). During the Howard government (1996-2007), for example, public subsidies for high-fee schools massively increased their resource levels to more than double the per capita resources available to public schools (Windle 2009: 233). At the state level, in New South Wales, the government 'dezoned' schools in the 1980s, enabling students to apply to attend schools outside of their local catchment area. In the same period, the number of academically-selective public schools was expanded, and this expansion has continued since. There are now 47 fully or partially selective schools in NSW, the majority located in Sydney (DEC 2015). These schools, catering for gifted and talented students, were designed in part to stem the flow away from the public education system.

Overall though, providing ‘choice’ has resulted in a large movement of middle-class families out of the government sector (Campbell 2005, Campbell et al. 2009, Connell 2011). Across 
Australia, the number of students attending non-government schools increased from $22 \%$ in 1980 to 35\% in 2013 (Evershed 2014). In NSW, public school enrolments increased by only 1\% between 2004 and 2013, compared to almost 10\% for non-government schools (McNeilage and Knott 2015).

Yet inequality is also growing within Australia's public system. Public schools in middleclass areas that have 'desirable’ students (i.e. those with the best potential to excel in external examinations) and capacity to raise funds from the parent community, have grown in size and academic strength (Windle 2009: 234). Other schools are left with the 'residual' student body - students from poorer backgrounds, including disadvantaged migrant backgrounds (Halse 2004).

These inequalities emerge in part because parents do not equally exercise choice. As Skeggs writes, 'choosing is a particularly middle-class way of operating in the world, dependent on access to resources and a sense of entitlement to others' (2004: 139). Typically, educated middle-class parents exercise choice by virtue of their capacity and interest in understanding and participating in schooling systems (Campbell et al. 2009, Forsey 2010b, Roda and Wells 2013).

By 'middle class', we refer to the cultural and normative practices bound up within 'class' identities that maintain differentiation from other socio-economic groups, and which reproduce inequalities. This is not a label defined by economic or material categories alone, but a cultural experience recreated in daily social interaction (Crompton 2005). As Bourdieu demonstrated, encultured practices relating to classed experiences, and acquired quite unconsciously, provide different advantages and disadvantages in the school field (1984: 107, 
165, 1986). The cultural logic of middle-class child rearing is far more in synch with the standards of schools and other institutions than that of working-class parents (Lareau 2003: 34, 8; Pugh 2009). Watkins and Noble (2013) further demonstrate how these encultured practices, developed within the home and necessary for successful participation in school, are patterned along ethnic as well as class lines.

In contrast to the choosing middle-class, research shows that parents from low-income and working-class backgrounds, including some migrant parents, have historically been more likely to send their children to their local public school. Such parents may prefer a school that is close to home, be less aware of differences between schools, and/or be less skilled in the practice of 'choosing' schools (Ball et al 1996, Kenway 2013, Raveaud and van Zanten 2007). However, this class division is neither homogenous nor applicable to all of Australia. Catholic schooling, for example, has a long association with the education of working-class families (Grace 2002). There is also anecdotal evidence of working-class families in Australia with economic capital choosing to move out of the public system (see Pini et al. 2012, Butler 2015). Yet by and large, polarisation along socio-economic divisions is occurring throughout Australia, often even within the same suburb (e.g. see Kenway 2013 for an analysis of segregation in schools in Geelong, Victoria).

The social consequences of school choice policies have been widely documented in many western nations, with researchers arguing that social cohesion is damaged and inequality worsened by a fragmented school system (e.g. Windle 2009, Halse 2004, Burgess and Wilson 2005, Frankenberg et al 2003, Lipman 2011). The OECD (2012: 92) states that 'Providing full parental school choice can result in segregating students by ability, socio-economic background and generate greater inequities across education systems'. However in Australia, 
there has been much less scholarly research on the social consequences of school choice, and even less on the intersection of education policy and gentrification (although see Gulson 2007). An established body of work has addressed the practice of school choice in relation to private schooling (e.g. Connell et al. 1982, Kenway 1984, Proctor 2011), and a growing body of literature has examined school choice in relation to inequality and social segregation in Australia (Marginson 1993, Campbell 2005, Campbell et al. 2009, Forsey 2008, Windle 2009, Connell 2011, Butler 2015). Yet these studies, while taking account of geography, have not addressed gentrification as a central component.

Our research aims to fill this gap, examining the implications of school choice for cultural diversity within school communities within the wider context of gentrification. As one of the world's key migrant destination countries, and one where school choice policies have been aggressively promoted, the Australian case can provide some rich insights. Additionally, in theorising modes of inter-cultural interaction within school communities, this paper enhances our understanding of what gentrification and school choice mean at the level of people’s everyday lives.

\section{Methods and data: Introducing Cooper and its schools}

Our research focuses on a gentrifying Sydney suburb that we call Cooper. Cooper is an innerurban suburb with a history of heavy industry and manufacturing, dating from the $19^{\text {th }}$ century. Manufacturing work and cheap housing attracted many post-World War 2 migrants, and Cooper became one of the most culturally diverse areas in Australia. Migrants from Europe and later Asia transformed its streetscapes. 
In the last two decades though, this trend has reversed, with increasing numbers of middleclass Anglo Australians moving into the area. According to the Census, in the decade to 2011, the proportion of Cooper residents working in professional jobs more than doubled (from $12 \%$ to $31 \%$ ), while the proportion speaking only English at home increased by more than ten percentage points (from 40\% to 51\%) (source: ABS 2001 and 2011 Census).

Cooper residents born in non-English speaking countries now tend to have lower incomes than Australian-born residents. In 2011, while only 46\% of Australian-born residents had a weekly personal income of less than $\$ 800$, the average figure was $75 \%$ for migrants from the main non-English speaking source countries, as Table 1 shows:

Table 1: Income by birthplace, Cooper 2011

\begin{tabular}{|l|l|}
\hline Birthplace & Personal weekly income less than \$800 (\%) \\
\hline Australia & 45.9 \\
\hline Southern \& Eastern Europe & 79.3 \\
\hline North Africa \& the Middle East & 73.9 \\
\hline South-east Asia & 76.9 \\
\hline North-east Asia & 72.1 \\
\hline Southern \& Central Asia & 74.8 \\
\hline
\end{tabular}

Source: ABS 2011 Census TableBuilder

Our research in Cooper is based on in-depth interviews conducted in 2014 with a sample of 20 parents, equally divided between two public primary schools. We also interviewed the schools’ principals and a school-based community worker. All parent respondents lived in 
Cooper at the time of interview, as well as having at least one child in either of the two schools under study.

Respondents were found primarily through snowball recruiting. We aimed for an approximate stratified sample, so that the demographic profile of our respondents could largely mirror the demographics of each school's community, for example, in terms of ethnicity and class. While this was achieved in the case of one school we call 'Cooper Hill', at the school we call 'Cooper Creek' interviewees were predominantly white. At both schools, we found that white middle-class gentrifiers had formed tightknit, ethnically homogenous communities, a point to which we return. Snowball recruiting resulted in a concentrated focus on this community at Cooper Creek, as interviewees referred us on to parents with whom they enjoyed relationships. Further research is needed to redress this imbalance. Interviews typically lasted 45 to 90 minutes, and covered topics such as respondents’ residential history, school choice decisions, and perceptions of social relations within their children’s school.

Given the small sample size, our findings should be considered preliminary. The research reported here is the first stage of an ongoing investigation into gentrification and schooling in Cooper. Our sample is not representative of all parents in the two schools, but elucidates the range of experiences that are present within Cooper's public schools at this time.

Interview research was complemented with analysis of data from the Census and the MySchool website, a website operated by the Australian Curriculum, Assessment and Reporting Authority (ACARA) that provides detailed profiles of all schools in Australia. 


\section{Polarisation and self-segregation in Cooper}

Cooper Creek and Cooper Hill Schools both have a long history of servicing disadvantaged, multicultural communities. However, in the last decade, Cooper Creek has become a highly desirable school for white middle-class gentrifiers, while Cooper Hill has come to be seen as the 'poor cousin' school. ${ }^{1}$ This polarisation is evident in the MySchool statistics (2013) on each school, in two main ways.

Firstly, the majority of Cooper Creek's families (60\%) are high income earners (within the top quarter income earners nationally). This is double the proportion at Cooper Hill (30\%). This difference is striking given that Census figures show that income profiles of the two schools' catchment areas are virtually identical. ${ }^{2}$

Secondly, as Cooper Creek's families have grown wealthier, they have also become whiter, with the proportion from a language background other than English (LBOTE) dropping to 29 per cent. At Cooper Hill, while LBOTE levels have been falling, LBOTE students still comprise a majority of the school, at 64 per cent. In both schools' catchment areas, Census figures show that approximately 55 per cent speak a non-English language (ABS 2011 Census). So Cooper Creek is disproportionately Anglo compared to its neighbourhood, while Cooper Hill is disproportionately non-Anglo.

School segregation is therefore more pronounced than neighbourhood segregation. In other words, the neighbourhoods of the two schools are more culturally mixed than the school

\footnotetext{
${ }^{1}$ These two schools are the only public primary schools in this part of the suburb. There are also two Catholic primary schools within the immediate area (within about one kilometre), and two other public primary schools in another part of the suburb (about two kilometres away).

${ }^{2}$ In both catchment areas, approximately 40 per cent of residents earn less than $\$ 800$ per week, while just over 20 per cent in each area earn between $\$ 800-\$ 2000$, and 5 per cent earn more than $\$ 2000$ (ABS 2011 Census).
} 
communities. This corroborates international research showing that education systems with school choice 'have schools with higher levels of economic, ethnic, and ability segregation than the levels in the neighbourhoods in which children reside' (Keels et al 2013: 242, see also Burgess et al 2005, Johnston et al 2006, Rangvid 2007).

Given that the distance between the two schools is just one kilometre, and that their catchment areas are virtually identical on all major indicators (income, education, labour market status, occupation, ethnicity), we can assume that the polarisation of the school communities largely reflects active choice among white middle-class families to send their children to Cooper Creek.

We interviewed a number of parents who lived in the catchment area of Cooper Hill but were attracted to Cooper Creek because of its reputation for high quality academic programs, especially music and arts programs. In the words of Will, ${ }^{3}$ an Anglo-Australian father, Cooper Creek is:

[...] more in tune with the changing lifestyle of the area, it's very hip and groovy, lots of musicians, lots of entertainers, lots of people in the entertainment industry tend to go to that school.

In contrast, two participants told us that middle-class white parents considering Cooper Hill appeared to do so with anxiety. The school's principal, Louise, informed us that she had had 'a lot of parents coming in saying, “Can you guarantee that my child won’t be disadvantaged by the fact that there are a lot of children in their class who did not start life speaking

\footnotetext{
${ }^{3}$ All respondent names are pseudonyms, and some personal details have been altered slightly in order to preserve the anonymity of respondents and schools.
} 
English?”' She added that this was a recent phenomenon, as more middle-class whites arrived in the neighbourhood. This mirrors international research showing white parents' concerns with the perceived English language skills of minority pupils, although Hamnett et al (2013: 569) remind us that English is 'widely and proficiently spoken among many Indian immigrants and amongst many children of migrants from Southeast Asia' (see Boterman 2013 for a similar experience in the Netherlands).

Louise recounted an incident where an Anglo-Australian mother had come for an interview with the principal and was convinced that Cooper Hill was the right school for her child. However, Louise continued, when this parent came to hand in the enrolment form, it was lunchtime, so the children were out in the playground. When she arrived at the school office, she asked the office worker, 'Do you always have this many coloured children in the playground?' She did not submit the form. Another interviewee, Wendy, an AngloAustralian, told us that she knew people who 'absolutely were never' going to send their kids to Cooper Hill: 'They would stand outside the school, look at the kids coming out, and say, "I don’t see anyone that I want my kids to be friends with”’.

This suggests that in Cooper, like many other areas, the practice of school choice effectively means that middle-class parents may follow an 'imperative of avoidance' (Hamnett et al 2013: 572), choosing to send their children to the 'desirable’ schools, which exacerbates divisions, even within the public system. The rest of the paper explores the implications of this division in terms of the ethnic composition of the two schools, and the prevalence of everyday and cosmo-multiculturalism within each school. 


\section{Everyday multiculturalism: normalising difference}

In the 'idealized gentrification scenario', gentrifying families enrol their children in the local public school, where they interact with children from different social and cultural backgrounds and learn from each other (Keels et al 2013: 240). Everyday multiculturalism in schools is made possible by gentrification, but, as we have previously argued (XXX), only when schools sufficiently reflect the diversity of the larger community. School choice has reduced social and cultural diversity in many schools, some of which have become islands of white middle-class privilege. This is particularly so at the elite level of high-fee private schools in wealthy suburbs (XXXX). In such environments, the cultural capital that comes with being middle-class and Anglo-Australian in Australian society is shored up within individual schools and their communities. However, similar trends are evident in local suburban public schools, as we can see in Cooper Creek, where now less than a third of students come from a language background other than English.

Some of our Cooper Creek respondents were acutely aware of the dominance of white students and families within the school. They mentioned that they had moved to Cooper for its cultural diversity, but soon realised that they were part of a movement that was displacing non-white residents. For example, Wendy explained that when she saw her daughter's kindergarten class photo:

I just cracked up because we all say, 'Oh, we moved to Cooper for the diversity! We love the diversity there!' And of the eight girls in her class, guess how many were not blonde? None! They were all blonde! (laughs) So it’s like, ‘The middle-class Anglo...is shoving that diversity out the door!' 
Another of our white respondents, Jim, stated that most of his daughter’s friends were children of migrants, and other parents also stressed that families of non-white backgrounds still attended the school. However, far more evident in both parents' narratives and the MySchool data is the dramatic reduction of cultural diversity within Cooper Creek. In fact, a dominant narrative within the interviews was the school's tight-knit community, one which was based on shared cultural and social backgrounds and values. In response to our question, 'What are the best aspects of the school?', every respondent from Cooper Creek cited the parent community, or the community values. As Wendy explained, 'On the whole, it's families with a similar values-base, I would say, to ours, so we have that in common'. Although almost a third of the school's students are from a non-English speaking background, multiculturalism did not feature in how our respondents spoke about the school community.

In contrast, Cooper Hill has a majority of students from language backgrounds other than English, representing about 40 different ethnicities, according to the principal, Louise. When asked to describe the school community, Louise's immediate response was to describe the ethnic makeup of the school, and how important multiculturalism was in the school's identity. This was echoed by parents at the school. In response to the question, 'What are the best aspects of this school?', the vast majority of Cooper Hill parents discussed cultural diversity. This included all the six non-white parents interviewed (two of whom were of Aboriginal rather than migrant descent) who often expressed relief that at this school, their children would not stand out. More positively, many listed the various nationalities found at the school ('Lebanese, Turkish, Vietnamese, Chinese, Bangladeshi', etc), proudly explaining how they and their children had friends from many different backgrounds, and that cultural difference was not a barrier. As Natalia, who is Spanish-Australian, stated: 
we're all together, and we all seem to be able to do it, you know...I am really happy that my children have the opportunity to go to school with children who are not Australian and that it's normal for them...I'm really, really happy and proud that we are able to do it especially because Australia - that's what Australia is.

Apart from these friendships, Natalia's pride centres on the work that she and other parents have done through a community centre based at the school. Over many years, groups of (mostly non-white) parents have worked together on initiatives such as playgroups, English classes, employment skills training, fundraisers and the various 'multicultural days' at the school. Almost always on a volunteer basis, these parents - supported by a paid community worker - have built an impressive community infrastructure which many respondents said makes the school distinctive.

Around a third of Cooper Hill's students come from a white background. The principal told us that she valued the way that such parents, in her view, worked to 'embrace' this aspect of the school 'rather than transform it'. This was echoed by the participants themselves. As Will stressed: 'one of the things we do like about our school is that it's not all middle-class whities. We like the fact that they, you know, come home with names that I can't pronounce, as friends.' Jen, another Anglo-Australian parent, stated: 'if we were in an area where they were at a school that was completely homogeneous then I just see that as such a missed opportunity, and for me it just doesn't reflect real life'. Another parent, Susan, an Aboriginal woman, enthused about her children's 'different nationality friends', at whose houses they had 'even had sleep-overs'. Susan had moved to Sydney from a regional town, and enjoyed 
the contrast with her own childhood where she attended a small primary school on an Aboriginal reserve.

These participants at Cooper Hill appeared to view multicultural engagement as an implicit part of people's everyday lives in the school. However, it was also evident that cross-cultural mixing was not evenly practised. Our respondents from non-Anglo migrant backgrounds all talked about the recent arrival of white Australians into the school community within the last five or so years. It was felt that their presence had changed the social dynamic of the school community. These interviewees effectively divided the school community into 'whites' and 'migrants', and (somewhat hesitantly) shared their frustrations with the sometimes exclusivist behaviour of white parents. As Rashimi, of Sri Lankan heritage, explained, white people 'don't want to share their experiences with us... they try to avoid'.

This division is especially manifested in the Parents and Citizens (P\&C) group, which is comprised almost entirely of white parents. Many of our interviewees commented that this group was 'unrepresentative' of the school. John, a white parent and a P\&C executive member, argued that there was insufficient effort on the part of the P\&C to diversify the group:

I've really noticed for example, people in the $\mathrm{P} \& \mathrm{C}$ don't necessarily reflect the cultural diversity of the school, and if you raise something about that, people say, 'well, we invited everyone to the meeting’. But I think you need to do more than that.

Natalia told us that she used to be active in the P\&C but withdrew as it became more 'AngloSaxon' and comprised of 'bigger personalities'. She explained, 'I don’t think it’s on purpose 
but their personality is really - and if you're a bit shy or English is your second language, it feels a bit... I felt it was a bit uncomfortable’. Natalia’s experience mirrors those of many working-class minority parents, who feel increasingly marginalised when parent bodies become dominated by middle-class professionals (Billingham and Kimelberg 2013, Cucchiara 2013a, Posey-Maddox 2013).

While interviewees spoke about this division primarily in ethnic terms, it was apparent that these experiences were shaped by factors which were deeply classed (Bourdieu 1984, Ortner 1998). The migrant parents we interviewed were more likely to be employed in low-paid service sector work, or primary carers without an independent source of income. The white Australians they viewed as excluding and/or avoiding them were highly educated and from middle-class, professional backgrounds. On entering the school, these latter parents appeared to have recreated a particular type of middle-class culture and habitus (Ortner 1998), as exemplified by their 'bigger personalities'. These were highly skilled people and, as Louise perceived, they 'go to meetings for a living'. Their confidence was experienced as a form of exclusion by parents from working-class migrant backgrounds.

This mirrors the demographic profile of Cooper overall, as discussed above. There are small numbers of working-class white families, and middle-class non-white families at the school. However, as is the case for the suburb as a whole, within the school, whiteness was typically associated by non-Anglo-Australians with class privilege. The practice and experience of everyday multiculturalism is therefore complicated by class and the unequal distribution of class-based privileges. Julie, the Anglo-Australian community worker at the school, made this clear when she explained that before gentrification affected Cooper Hill, the school community was a 'level playing field'. Although families were from different countries, Julie 
continued, all were relatively recent arrivals and shared a comparatively low socio-economic status. These circumstances were conducive to cross-cultural engagement. The influx of middle-class Anglo-Australians was seen to have disrupted this dynamic, and the school community is still adapting to the changes this has brought.

\section{Cosmo-multiculturalism: Consuming difference}

Gentrifiers at both Cooper Hill and Cooper Creek can be largely characterised as part of the 'new middle class’ discussed above, who often define themselves as cosmopolitan and progressive. Drawing on Butler’s (1997) work, we identify these middle-class gentrifiers as typically public sector or creative industry professionals with lower incomes but high cultural capital, as compared to private sector professionals on high incomes with more socially conservative orientations. Their appreciation of diversity fits neatly with their progressive worldviews and cultural sophistication, and they value cross-cultural competency as a professional asset.

The interest in fostering this 'cosmopolitan capital' is evident in our study. At Cooper Creek, the proportion of non-white students had fallen so dramatically that the school was no longer funded to provide community language classes in its curriculum. However, so many parents valued foreign language learning that the $\mathrm{P} \& \mathrm{C}$ instituted its own classes, before and after school, in five languages: Spanish, German, Arabic, Greek and Chinese. Most languages reflect the families present in the school, with the exception of Chinese. As Wendy explained, there are not a lot of Chinese speakers at the school but, 'It's because Western parents like the 
idea of their kids learning Chinese'. In this instance, Chinese is offered not as a community language, but as a language with obvious future professional applications.

Cooper Creek's cosmo-multiculturalist credentials are also evident in its success in the annual state-wide Multicultural Perspectives Public Speaking Competition, where students prepare speeches on set multicultural topics. In his interview, Cooper Creek’s principal proudly highlighted the school's record in producing finalists in this competition. However, as one of our respondents, Fiona, an Anglo-Australian mother, complained:

Every year you see the whitest, most Anglo-Saxon kids standing up, winning that competition, talking about the United Nations Conventions, with no basis from their own life experience, and the kids who really have a greater insight into that are completely silent and...it's quite awful... So I think there's a dominant culture in the school that does silence a lot of the actual diversity that is there.

The parents' commitment to foreign language classes at Cooper Creek is matched by their enthusiasm for arts and music. The school is well-known for its performance groups, and offers an extensive range of arts and music programs, including bands, musical theatre, theatresports, and dance. Many of these initiatives are run by parent volunteers (cf. Billingham and Kimelberg 2013: 97). More than one respondent characterised the parents as 'artsy fartsy types', a characterisation that fits well with the profile of the cosmopolitan figure described by Hage (1997) who appreciates 'high quality’ culture. The commitment to arts and music, like foreign languages, is a mark of Cooper Creek’s cosmopolitan and cosmomulticultural credentials, and a form of cultural capital with strong currency beyond the school. 
Meanwhile, at Cooper Hill, white middle-class parents appreciate the cosmopolitan capital being accrued by their children in attending a culturally diverse school. As in Reay et al's study (2007), our respondents discussed values they wished to see cultivated in their children, such as worldliness, self-awareness and openness. These values are best inculcated in a school that reflects 'real life', as Jen stated. She and other parents might reassure themselves that while their children risk falling behind academically, as teachers' energies are absorbed by children who might be seen to lack a 'scholarly habitus' (Watkins and Noble 2013), this concern is, in Jen's words, 'outweighed by the overall experience’ of contact with cultural diversity.

However, the valorisation of diversity sometimes stops short of developing friendships with ethnic others, such that some middle-class white parents at Cooper Hill could be said to practise Hage’s ‘multiculturalism without migrants’. This mirrors Blokland and van Eijk’s finding that the social networks of gentrifiers professing to value and enjoy diversity were no more diverse than the networks of others who professed no such preference (2010: 328). At Cooper Hill, Will, as noted above, liked the fact that his children had friends with names 'that I can’t pronounce'. However, others, despite reporting that they'd moved to Cooper for its multiculturalism, acknowledged that their children's friendship circles were not diverse. For example, Lucy, an Anglo-Australian woman, talked at length about the school's diversity as something that 'excited' her and her husband. But the children's social networks were a different question: 
[...] my observation is that still, you have those sub-cultures [based on ethnicity]... I would love to be able to say that my children, they're best friends with kids from a Nepalese background, or ... and it's not the case. And that disappoints me.

The difference between the two schools then, is one of degree. Both everyday and cosmomulticulturalisms are practised in both locations, but in differing amounts. The higher levels of cultural diversity at Cooper Hill allow for more interactions approximating everyday multiculturalism, compared to Cooper Creek. However, even at the former school, the everyday mixing appears to be concentrated among migrants. Cosmo-multiculturalism is a better description of the practices of the middle-class whites, at both Cooper Hill and Cooper Creek. At the latter though, the numerical dominance of Anglo-Australians has meant that this mode of multiculturalism has become the dominant approach.

\section{Conclusion}

In Australia, the impact of gentrification on local schools has been exacerbated by policies of school choice. One result has been the rise in number of middle-class parents opting out of local public schools in favour of private schools or more desirable public schools. In some cases, this has worsened existing divisions and inequalities between schools, including between public schools. Our research has examined the implications of these changes for cultural diversity within school communities, and identified two distinct modes of multiculturalism practiced across both schools, which are also affected by classed cultural capital. 
These different modes of ‘doing diversity’ represent just one dimension of the social consequences of gentrification and school choice. They are part of the well-documented division and segregation that result from communities being fragmented by the marketization of social practices, with the long-standing marketization of housing now combined with the more recent intensification of the marketization of education. Our research has shown that these processes have driven apart even local public school communities within the same suburb, with worrying implications for multicultural social relations and for social justice.

\section{Works Cited}

ABS (Australian Bureau of Statistics) 2011 Census data.

http://www.abs.gov.au/websitedbs/censushome.nsf/home/quickstats?opendocument\&navpos $\underline{=220}$ [Accessed: 20 October 2014].

Amin, A., 2002. Ethnicity and the Multicultural City: Living with diversity. Environment and Planning A, 34 (6), 959-980.

Ang, I., et al., 2002. Living diversity: Australia's multicultural future. Sydney: Special Broadcasting Service.

Ball, S. J., Bowe, R., \& Gewirtz, S., 1996. School choice, social class and distinction: The realization of social advantage in education. Journal of Education Policy, 11 (1), 89-112.

Billingham, C. M. and Kimelberg, S. M., 2013. Middle-class parents, urban schooling and the shift from consumption to production of urban space. Sociological Forum, 28 (1), 85-108. 
Blokland, T. and van Eijk, G., 2010. Do people who like diversity practice diversity in neighbourhood life? Neighbourhood use and the social networks of 'diversity-seekers' in a mixed neighbourhood in the Netherlands. Journal of Ethnic and Migration Studies, 36 (2), 313-332.

Boterman, W. R., 2013. Dealing with diversity: Middle-class family households and the issue of 'black' and 'white' schools in Amsterdam. Urban Studies, 50 (6), 1130-1147.

Bounds, M., and Morris, A., 2006. Second wave gentrification in inner-city Sydney. Cities, 23 (2), 99-108.

Bourdieu, P., 1984. Distinction: A Social Critique of the Judgement of Taste. Trans. Richard Nice, London and New York: Routledge.

Bourdieu, P., 1986. The forms of capital. In J. Richardson (ed) Handbook of Theory and Research for the Sociology of Education. New York: Greenwood, pp. 241-258.

Bridge, G., 2006. It's not just a question of taste: Gentrification, the neighbourhood, and cultural capital. Environment and Planning A, 38 (10), 1965-1978.

Bridge, G. and Dowling, R., 2001. Microgeographies of Retailing and Gentrification. Australian Geographer, 32 (1), 93-107. 
Burgess, S. and Wilson, D., 2005. Ethnic Segregation in England's Schools. Transactions of the Institute of British Geographers, 30 (1), 20-36.

Burgess, S., et al. 2005. Parallel lives? Ethnic segregation in schools and neighbourhoods. Urban Studies, 42 (7), 1027-1056.

Butcher, M. and Harris, A., 2010. Pedestrian Crossings: Young People and Everyday Multiculturalism. Journal of Intercultural Studies, 31 (5), 449-453.

Butler, R., 2015. Schools, “ferals”, stigma and boundary work: Parents managing education and uncertainty in regional Australia. Special Issue. Late Modernity and Schooling: Rural Perspectives. Ethnography and Education DOI: 10.1080/17457823.2015.1051071.

Butler, T., 1997. Gentrification and the Middle Classes. Aldershot: Ashgate.

Butler, T., 2003. Living in the bubble: Gentrification and its 'others' in North London. Urban Studies, 40 (13), 2469-2486.

Butler, T. and Robson, G., 2003. Plotting the Middle Classes: Gentrification and Circuits of Education in London. Housing Studies, 18 (1), 5-28.

Campbell, C., 2005. Changing school loyalties and the middle class: A reflection on the developing fate of state comprehensive high schooling. Australian Educational Researcher, 32 (1), 3-24. 
Campbell, C., Proctor, H. and Sherington, G., 2009. School choice: How parents negotiate the new school market in Australia. Crows Nest: Allen \& Unwin.

Connell, R. 2011. Confronting Equality: Gender, Knowledge and Global Change. Allen \& Unwin: Sydney, Melbourne, Auckland and London.

Connell, R.W., Ashenden, D., Kessler, S. and Dowsett, G., 1982. Making the difference: Schools, families and social division. Sydney: George Allen and Unwin.

Crompton, R., 2005. Class and Family. The Sociological Review, 54 (4), 658-677.

Cucchiara, M., 2013a. Marketing Schools, Marketing Cities: Who Wins and Who Loses when Schools become Urban Amenities. Chicago: University of Chicago Press.

Cucchiara, M., 2013b. 'Are We Doing Damage?' Choosing an Urban Public School in an Era of Parental Anxiety. Anthropology and Education Quarterly, 44 (1), 75-93.

DEC (Department of Education and Communities), 2015. Secondary schools - selective high schools, http://www.schools.nsw.edu.au/gotoschool/types/selectiveschools.php [Accessed: 23 June 2015].

Evershed, N., 2014. Datablog: Private schools are winning over Australian parents. The Guardian 11 March, http://www.theguardian.com/world/datablog/2014/mar/11/datablogprivate-schools-are-winning-over-australian-parents [Accessed: 15 July 2015]. 
Florida, R., 2003. Cities and the Creative Class. City and Community, 2 (1), 3-19.

Forsey, M., 2008. No choice but to choose: selecting schools in Western Australia. In: M. Forsey, S. Davies and G. Walford, eds. The globalisation of school choice? Oxford: Symposium Books, 73-93.

Forsey, M., 2010a. Publicly minded, privately focused: Western Australian teachers and school choice. Teaching and Teacher Education, 26 (1), 53-60.

Forsey, M., 2010b. Teachers and the re-production of middle-class culture in Australian schools. International Studies in Sociology of Education, 20 (1), 67-81.

Frankenberg, E., Lee, C. et al. 2003. A Multiracial Society with Segregated Schools: Are We Losing the Dream? Civil Rights Project, Harvard University.

Glass, R., 1964. London: Aspects of Change. London: Centre for Urban Studies and MacGibbon and Kee.

Grace, G., 2002. Catholic schools: Mission, markets and morality. London: Falmer Press.

Greig, A., Lewins, F. and White, K., 2003. Inequality in Australia. Cambridge: Cambridge University Press. 
Gulson, K. N., 2007. Repositioning Schooling in Inner Sydney: Urban Renewal, an Education Market, and the 'Absent Presence' of the 'Middle Classes'. Urban Studies, 44 (7), 1377-1391.

Hage, G., 1997. At Home in the Entrails of the West: Multiculturalism, Ethnic Food and Migrant Home-Building. In: H. Grace, G. Hage, L. Johnson, J. Langsworth and M. Symonds, Home/World: Space Community and Marginality in Sydney's West. Sydney, Pluto Press, 99153.

Hage, G., 1998. White Nation: Fantasies of White supremacy in a multicultural society. Sydney: Pluto Press.

Hamnett, C., Butler, T., and Ramsden, M., 2013. 'I wanted my child to go to a more mixed school': Schooling and ethnic mix in East London. Environment and Planning A, 45, 553574.

Halse, C., 2004. Striving for balance: Australian perspectives on the future of schooling. International Journal of Educational Research, 41 (7-8), 523-533.

Hankins, K. B., 2007. The final frontier: Charter schools as new community institutions of gentrification. Urban Geography, 28 (2), 113-128.

Harris, A., 2013. Young People and Everyday Multiculturalism. Hoboken: Taylor and Francis. 
Harris, A. 2014. Conviviality, Conflict and Distanciation in Young People’s Local Multicultures. Journal of Intercultural Studies, 35 (6), 571-587.

Ho, C., 2011, Respecting the Presence of Others: School Micropublics and Everyday Multiculturalism. Journal of Intercultural Studies, 32 (6), 605-621.

Johnston, R., et al. 2006. School and residential segregation: An analysis of variations across England's Local Education Authorities. Regional Studies, 40 (9), 973-990.

Keels, M., Burdick-Will, J., and Keene, S., 2013. The effects of gentrification on neighborhood public schools. City and Community, 12 (3), 238-259.

Kelly, A., 2009. Juxtaposing some contradictory findings from research on school choice. Magis: Revista Internacional de Investigacion en Educacion, 2 (3), 261-274.

Kenway, J., 1984. The ties that bind: Old girls’ and old boys’ associations. Discourse: Studies in the Cultural Politics of Education 5: 1-18.

Kenway, J., 2013. Challenging Inequality in Australian Schools: Gonski and Beyond. Discourse: Studies in the Cultural Politics of Education, 34 (2), 286-308.

Kimelberg, S. M. and Billingham, C. M., 2013. Attitudes toward diversity and the school choice process: Middle-class parents in a segregated urban public school district. Urban Education, 48 (2), 198-231. 
Lareau, A., 2003. Unequal Childhoods: Class, Race, and Family Life. Berkeley: University of California Press.

Ley, D., 1986. Alternative explanations for inner-city gentrification: A Canadian assessment. Annals of the Association of American Geographers, 76 (4), 521-535.

Lipman, P., 2011. The New Political Economy of Urban Education: Neoliberalism, Race, and the Right to the City. London: Routledge.

Marginson, S., 1993. Education and Public Policy in Australia. Cambridge University Press: Cambridge and Melbourne.

May, J., 1996. Globalization and the politics of place and identity in an inner city London neighbourhood. Transactions of the Institute of British Geographers, 21 (1), 194-215.

McNeilage, A. and Knott, M., 2015. NSW families abandon public schools in favour of private education. The Sydney Morning Herald, February 6. http://www.smh.com.au/national/education/nsw-families-abandon-public-schools-in-favourof-private-education-20150205-1377lg.html\#ixzz3fvb5IZf9 [Accessed: 15 July 2015].

Noble, G., 2013. Cosmopolitan Habits: The Capacities and Habitats of Intercultural Conviviality. Body \& Society, 19 (2\&3), 162-185. 
OECD, 2012. Equity and Quality in Education: Supporting Disadvantaged Students and Schools. http://www.oecd-ilibrary.org/education/equity-and-quality-ineducation_9789264130852-en [Accessed: 12 December 2014].

Ortner, S., 1998. Identities: The Hidden Life of Class. Journal of Anthropological Research, $54(1), 1-17$.

Posey-Maddox, L., 2013. Professionalizing the PTO: Race, class and shifting norms of parental engagement in a city public school. American Journal of Education, 119 (2), 235260.

Proctor, H., 2011. Masculinity and social class, tradition and class: the production of 'young Christian gentlemen' at an elite Australian boys' school. Gender and Education 23 (7), 843856.

Pugh, A., 2009. Longing and Belonging: Parents, Children, and Consumer Culture. Berkeley and London: University of California Press.

Rangvid, B. S., 2007. Living and Learning Separately? Ethnic Segregation of School Children in Copenhagen. Urban Studies, 44 (7), 1329-1354.

Raveaud, M. and Van Zanten, A., 2007. Choosing the local school: Middle-class parents' values and social and ethnic mix in London and Paris. Journal of Education Policy, 22 (1), 107-124. 
Reay, D., et al, 2007. 'A Darker Shade of Pale?’ Whiteness, the Middle Classes and MultiEthnic Inner City Schooling. Sociology, 41 (6), 1041-1060.

Roda, A. and Wells, A. S., 2013. School choice policies and racial segregation: Where white parents' good intentions, anxiety and privilege collide. American Journal of Education, 119 (February), 261-293.

Skeggs, B., 2004. Class, Self, Culture. Routledge: London and New York.

Tonkiss, F., 2005. Space, the City and Social Theory. Cambridge: Polity Press.

Watkins, M. and Noble, G., 2013. Disposed to Learn: Schooling, Ethnicity and the Scholarly Habitus. London: Bloomsbury Academic.

Windle, J., 2009. The limits of school choice: Some implications for accountability of selective practices and positional competition in Australian education. Critical Studies in Education, 50 (3), 231-246.

Wise, A. and Velayutham, S. 2009. Introduction: Multiculturalism and Everyday Life. In: A. Wise and S. Velayutham, eds. Everyday Multiculturalism. London: Palgrave Macmillan, 117. 